\title{
Synthesis, characterization, and evaluation of the antimicrobial efficacy of Boswellia ovalifoliolata stem bark-extract-mediated zinc oxide nanoparticles
}

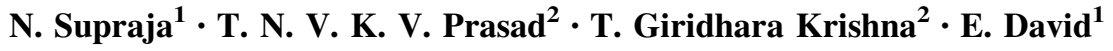

Received: 27 April 2015/ Accepted: 12 June 2015/Published online: 23 June 2015

(C) The Author(s) 2015. This article is published with open access at Springerlink.com

\begin{abstract}
Synthesis of metal nanoparticles using biological systems is an expanding research area in nanotechnology. Moreover, search for new nanoscale antimicrobials is been always attractive as they find numerous avenues for application in medicine. Biosynthesis of metallic nanoparticles is cost effective and eco-friendly compared to those of conventional methods of nanoparticles synthesis. Herein, we present the synthesis of zinc oxide nanoparticles using the stem bark extract of Boswellia ovalifoliolata, and evaluation of their antimicrobial efficacy. Stable $\mathrm{ZnO}$ nanoparticles were formed by treating $90 \mathrm{ml}$ of $1 \mathrm{mM}$ zinc nitrate aqueous solution with $10 \mathrm{ml}$ of $10 \%$ bark extract. The formation of B. ovalifoliolata barkextract-mediated zinc oxide nanoparticles (BZnNPs) was confirmed by UV-visible spectroscopic analysis and recorded the localized surface plasmon resonance (LSPR) at $230 \mathrm{~nm}$. Fourier transform infrared spectroscopic (FTIR) analysis revealed that primary and secondary amine groups in combination with the proteins present in the bark extract are responsible for the reduction and stabilization of the BZnNPs. The morphology and crystalline phase of the nanocrystals were determined by Transmission electron microscopy (TEM). The hydrodynamic diameter $(20.3 \mathrm{~nm})$
\end{abstract}

T. N. V. K. V. Prasad

tnvkvprasad@gmail.com

E. David

ernestdavid2002@yahoo.com

1 Department of Biotechnology, Thiruvalluvar University, Serkadu, Vellore 632001, India

2 Nanotechnology Laboratory, Institute of Frontier Technology, Regional Agricultural Research Station, Acharya N G Ranga Agricultural University, Tirupati 517 502, AP, India and a positive zeta potential $(4.8 \mathrm{mV})$ were measured using the dynamic light scattering technique. The antimicrobial activity of BZnNPs was evaluated (in vitro) against fungi, Gram-negative, and Gram-positive bacteria using disk diffusion method which were isolated from the scales formed in drinking water PVC pipelines.

Keywords Zinc nanoparticles · Fungi - Gram-negative bacteria $\cdot$ Gram-positive bacteria $\cdot$ Boswellia ovalifoliolata

\section{Introduction}

The development of green processes for the synthesis of nanoparticles has been evolving into an important branch of nanotechnology as green nanotechnology deals with the safe and eco-friendly methods for nanomaterials fabrication and which is considered as an alternative to conventional physical and chemical methods (Mohanpuria et al. 2008). Nanomaterials exhibit unique and considerably changed physical, chemical, and biological properties compared to their bulk counterparts (Singh et al. 2011). Although physical and chemical methods (Prasad et al. 2012) are more popular for nanoparticle synthesis, the use of toxic compounds limits their applications (Salam et al. 2012). Indeed, over the past several years, plants, algae, fungi, bacteria, and viruses have been used for production of metallic nanoparticles (Kaushik et al. 2010). Green synthesis of metallic nanoparticles from plants (Girija et al. 2009) is been an interesting aspect as the process is ecofriendly and non-toxic. Plant and plant materials have become potential sources for the synthesis of metallic nanoparticles recently. A number of researchers have reported on synthesis of metallic nanoparticles including silver (Prabha et al. 2014), gold (Sreekanth et al. 2014), 
titanium dioxide (Sundrarajan and Gowri 2011), tungsten oxide (Gunalan et al. 2012), and copper oxide (Padil and Cernik 2013) using different plant materials. But reports on synthesis of zinc nanoparticles using plant materials are scant (Kim et al. 2011).

Boswellia ovalifoliolata Bal \& Henry is a narrow endemic, endangered and threatened medicinal tree species. It is a deciduous medium-sized tree belongs to the family Burseraceae. This tree harbors on Tirumala hills of Seshachalam hill range of Eastern Ghats of India. The plant is used by tribals like Nakkala, Sugali, and Chenchu and indigenous community to treat number of aliments. The plant is over exploited for its medicinal uses; especially the stem bark is used to reduce rheumatic pains (Savithramma 2011; Sinha et al. 2010). Stem bark decoction is given orally to reduce the pains. Equal mixture of Gum \& Stem bark one tea spoon full is given daily with sour milk in an empty stomach for a month to cure stomach ulcers. Zinc nanoparticles are widely used for its unique properties in catalysis, chemical sensing, biosensing, photonics, electronic, and pharmaceuticals (Sarkar et al. 2010) and in biomedicine especially for antibacterial agent (Rai et al. 2009) and antiviral agent (Elechiguerra et al. 2005). Zinc nanoparticles have a great potential for use in biological including antimicrobial activity (Sap-Iam et al. 2010).

$\mathrm{ZnO}$ nanoparticles appear to be strongly resistant to bacteria and fungi (Huang et al. 2001). The present study reports for the first time on the synthesis characterization and antibacterial and antifungal efficacy of $B$. ovalifoliolata Bal \& Henry bark-extract-mediated zinc oxide nanoparticles. The antimicrobial activity (Biofilm degradation in drinking water pipelines) BZnNPs were evaluated against pathogenic fungi and bacteria isolated from the biofilm formed in drinking water PVC pipelines by in vitro using disk diffusion method.

\section{Materials and methods}

\section{Chemicals}

Zinc nitrate ( $>99 \%$ pure) was purchased from Sigma Aldrich, India. Potato dextrose broth, Potato dextrose agar, Nutrient broth, and Nutrient agar plate were supplied by Hi-media, India.

\section{Collection of biofilm formed in polyvinyl chloride (PVC) pipes}

The PVC Biofilm samples were collected from four different regions located in and around Tirupati, (Chittoor District) Andhra Pradesh, India. The samples were collected from drinking water PVC pipelines and taken in the sterile container. These samples were stored in an ice box and transported to the laboratory for microbiological characterization.

\section{Collection of plant material}

Healthy B. ovalifoliolata stem barks were collected from Tirumala hills, Andhra Pradesh state, India. From the selected plant, bark was collected by scrapping the trunk using neat and clean knife during the month of June 2014, and collected material was carefully washed and dried at $45^{\circ} \mathrm{C}$ to constant weight. The dried bark of plant material was powdered, passed through a BSS no. 85-mesh sieve, and stored in air-tight container.

\section{Preparation of aqueous bark extract}

The collected $B$. ovalifoliolata stem bark was allowed to shade dried for $72 \mathrm{~h}$ and was ground to get fine powder. Then, $10 \mathrm{~g}$ of powder was mixed with $100 \mathrm{~mL}$ of distilled water (DW unit, Bhanu industries, Banglore) and boiled for $30 \mathrm{~min}$. After that, the extract was filtered by using Whatman No. 1 filter paper and collected the filtrate in plastic bottle and stored at $4{ }^{\circ} \mathrm{C}$ for further experimentation.

\section{Isolation of fungal and bacterial sp. from drinking water pipeline}

Eight fungal species and ten bacterial samples were isolated from drinking water supply PVC pipelines in Tirupati, Chittoor district, Andhra Pradesh, India. Through serial dilution pour plate technique, fungal sp. was isolated using potato dextrose agar (PDA) medium, and Gramnegative and Gram-positive bacteria were isolated from nutrient agar medium. Further, it is maintained in potato dextrose agar slants (fungi) and nutrient agar slants (bacteria) for onward analysis (Bhattacharya and Zaman 2005).

\section{Preparation of Boswellia ovalifoliolata $\mathrm{ZnO}$ nanoparticles}

$90 \mathrm{~mL}$ aqueous solution of $1.0 \times 10^{-3} \mathrm{M}$ Zinc nitrate was mixed with a $10 \mathrm{~mL}$ of $10 \%$ aqueous solution of $B$. ovalifoliolata stem bark extract. The samples were then centrifuged using REMI $\mathrm{K}_{70}$ at $4000 \mathrm{rpm}$ (2146 g) for $15 \mathrm{~min}$ to get clear supernatant. The initial concentration of the BZnNPs was measured using inductively coupled plasma optical emission spectrophotometer (ICP-OES) and was found to be $296 \pm 0.8 \mathrm{ppm}$. Then, the sample was diluted to different concentrations of 170, 100, and $50 \mathrm{ppm}$ and they were used to investigate the concentration-dependent antimicrobial effect of BZnNPs. 
Concentration of BZnNPs is measured using inductively coupled plasma optical emission spectrophotometer (ICPOES) (Prodigy XP, Leeman Labs, USA).

The concentrations of the BZnNPs were measured using ICP-OES (Prodigy XP, Leeman Labs, USA). The samples were prepared with ten times dilution after centrifugation at $4000 \mathrm{rpm}$ for $15 \mathrm{~min}$. Then, $20 \mathrm{ml}$ of aliquot was loaded to the racks of automatic sampler, and the concentration of BZnNPs was estimated thrice.

\section{Assay for antimicrobial activity of BZnNPs}

The antimicrobial activity of BZnNPs was determined on the basis of colony formation (CFU) by in vitro petri dish assays (disk diffusion). Each fungal and bacterial isolates were cultured on growth media that induced prolific conidia and bacterial production. The fungi isolates were grown on potato dextrose agar medium, and bacterial isolates were grown on nutrient agar medium. Conidia were collected from cultures that were incubated at $37{ }^{\circ} \mathrm{C}$ for 10 days (fungi), and bacterial cultures were collected from cultures that were incubated at $37^{\circ} \mathrm{C}$ for 2 days for (bacteria) and diluted with sterile, deionized water to a concentration of 106 spores $\mathrm{ml}^{-1}$. Aliquots of the conidial suspension and bacterial suspensions were mixed with serial concentrations of silver preparations to a final volume of $1 \mathrm{ml}$ and were also mixed with sterile, deionized water as control. A $10 \mu \mathrm{l}$ subsample of the conidia and $B$. ovalifoliolata $\mathrm{Zn}$ mixture stock was taken at $50 \pm 0.9$, $100 \pm 1.1$ and $170 \pm 1.4 \mathrm{ppm}$ after $\mathrm{Zn}$ treatments and diluted 100-fold with the deionized water. A $10 \mu \mathrm{l}$ aliquot of the diluted spore suspension was spread on PDA (Becton, Dickson and Company, Sparks, MD) medium. Three PDA plates for fungi and three NA plates for bacteria per each combination of exposure $B$. ovalifoliolata $\mathrm{Zn}$ concentration were tested. The filter paper disk was dipped in different ppm and inserted on mediums (PDA), and then the plates were incubated at $37{ }^{\circ} \mathrm{C}$ for $2-4$ days for fungi and bacteria, respectively. The average number of colonies from silver-treated spore suspensions (fungi) and (bacteria) was compared with the number on the water control (percent colony formation). The zone size was determined by measuring the diameter of the zone in mm (Cynthia and Callaghan 1983; Yamac and Bilgili 2006; Reeves and White 1999).

\section{Characterization of $\mathrm{Zn}$ nanoparticles}

\section{$U V$-visible spectrum for synthesized nanoparticles}

The bioreductant nanoparticles were monitored by UVvisible (UV-vis) spectrum at various time intervals. The $\mathrm{UV}-\mathrm{vis}$ spectra of this solution were recorded (UV-
2450, SHIMADZU Spectrophotometer) from 200 to $400 \mathrm{~nm}$.

\section{FTIR analysis for synthesized nanoparticles}

The FTIR spectrum was taken in the mid-IR region of $400-4000 \mathrm{~cm}^{-1}$. The spectrum was recorded using ATR (attenuated total reflectance) technique. The dried sample was mixed with the $\operatorname{KBr}(1: 200)$ crystal, and the spectrum was recorded in the transmittance mode (Tensor 27, BRUKER).

\section{X-ray diffraction (XRD) analysis for synthesized nanoparticles}

The phyto-reduced zinc nanoparticles were characterized to reveal their crystal structure using X-ray diffraction technique. The XRD pattern was recorded using computercontrolled XRD-system (JEOL, and Model: JPX-8030) with $\mathrm{CuK} \alpha$ radiation (Ni filtered $=13418 \AA$ ) in the range of $40 \mathrm{kV}, 20 \mathrm{~A}$. The built-in software (syn master 7935) program was used for the identification of XRD peaks corresponding to the Bragg's reflections.

\section{Particle size and zeta potential analysis of $\mathrm{ZnO}$ nanoparticles}

The aqueous suspension of the synthesized nanoparticles was filtered through a $0.22-\mu \mathrm{m}$ syringe driven filter unit, and the size and distribution of the nanoparticles were measured using dynamic light scattering technique (Nanopartica, HORIBA, SZ-100).

\section{Transmission electron microscopy (TEM)}

The surface morphology and size of the nanoparticles were studied by transmission electron microscopy [JEOL (JEM1010)] with an accelerating voltage of $80 \mathrm{kV}$. A drop of aqueous BZnNPs on the carbon-coated copper TEM grid was dried and kept under vacuum in desiccators before loading them onto a specimen holder. The particle size and surface morphology of nanoparticles were evaluated using Image J $1.45 \mathrm{~s}$ software.

\section{Statistical analysis}

All of the data from three independent replicate trials were subjected to analysis using Statistical package for the Social Sciences (SPSS) version 16.0. The data are reported as the mean $\pm \mathrm{SD}$, and significant differences between mean values were determined with one-way analysis of variance (CRD) followed by Duncan's multiple range test (DMRT) $(P \leq 0.05)$. 


\section{Results and discussion}

\section{Selection of fungi and bacteria present in drinking water pipeline and synthesis of $\mathrm{Zn}$ nanoparticles}

Drinking water pipeline bacteria and fungi species have unusual biological activities depending upon the metabolisms under temperature, $\mathrm{pH}$, and pressure. Once the bark (Fig. 1) extract $(10 \mathrm{ml})$ was treated with $90 \mathrm{ml}$ of $\mathrm{Zn}$ nitrate solution, the color of zinc nitrate solution is colorless when mixing with $B$. ovalifoliolata shown pale yellow color (Fig. 2). BZnNPs were characterized by using the techniques like, Fourier transform infrared spectrophotometry, (FTIR), UV-vis spectrophotometry, dynamic light scattering (Particle size), zeta potential, and transmission electron microscopy (TEM).

\section{UV-visible spectral analysis}

The absorption spectrum was recorded for the sample in the range of 200-800 $\mathrm{nm}$ (Fig. 3). The spectrum showed the absorbance peak at $240 \mathrm{~nm}$ corresponding to the characteristic LSPR band of $\mathrm{ZnO}$ nanoparticles. The biomatrix present in the stem bark extract of B. ovalifoliolata may lead to the change in the absorbance UV-Vis micrograph (Gunalan et al. 2012; Revina et al. 2007). The bioreduction of zincs is extracellular and promises the vast development of green synthesis of metallic nanoparticles using the plants and plant bark sources.

\section{FTIR analysis}

The functional groups-alcohols, phenols, alkenes, alkanes, carbonyls, aromatics, nitro-compounds, alkyl halides, and aliphatic amines-were identified from FTIR spectrum recorded from the bark extract of B. ovalifoliolata (Fig. 4).

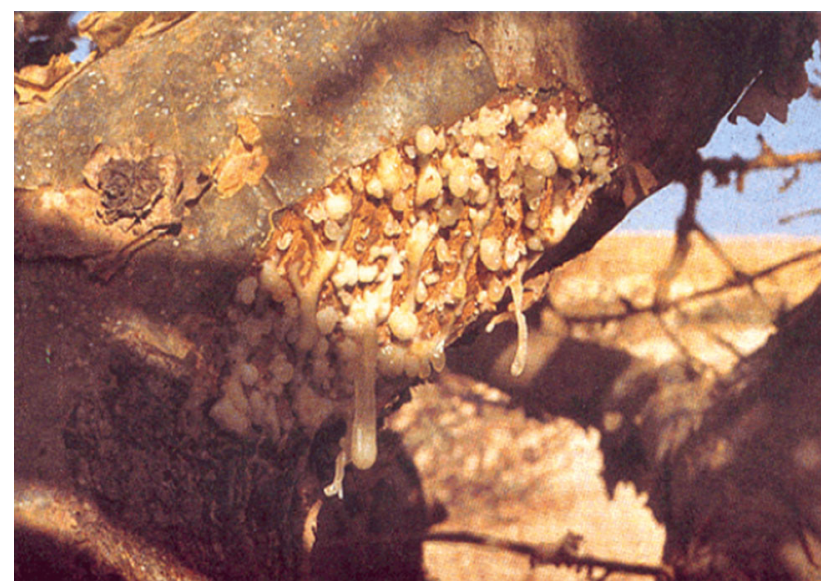

Fig. 1 Photograph showing Boswellia ovalifoliolata Stem Bark

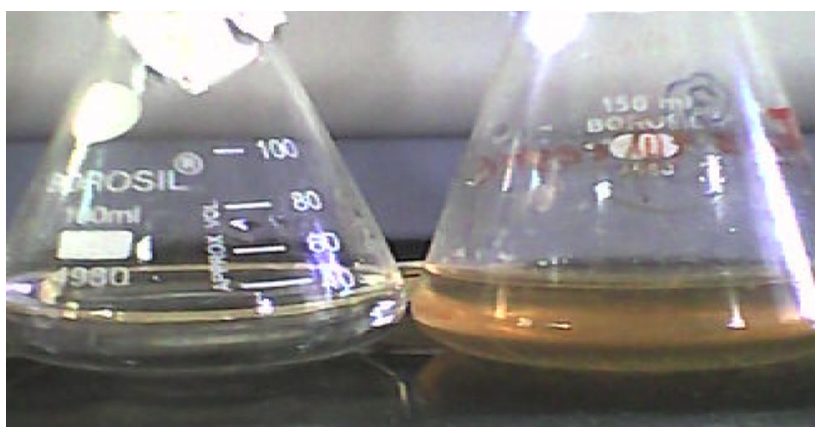

Fig. 2 Change of color of the solution confirms the formation of Zinc nanoparticles by Boswellia ovalifoliolata stem bark

The spectrum showed the bands for the functional groups located at $3361.18,2106.47,1638.14,1355.28$, and $575.81 \mathrm{~cm}^{-1}$. The peaks at 3361 and $2106 \mathrm{~cm}^{-1}$ reveal the presence of $\mathrm{N}-\mathrm{H}$ bend, indicating the primary and secondary amine groups of protein, respectively. The strong band of $-\mathrm{C}=\mathrm{O}-$ stretch (carboxylic acids) was recorded at $1638.14 \mathrm{~cm}^{-1}$. The medium bands of $-\mathrm{C}-\mathrm{N}-$ stretch (aromatic amines) and $-\mathrm{CH}_{2}-\mathrm{X}$ stretch (alkyl halides) were recorded at $1355.28 \mathrm{~cm}^{-1}$. And the band present at $575.81 \mathrm{~cm}^{-1}$ indicates the presence of $\mathrm{C}-\mathrm{Br}$ stretching vibration. From the FTIR spectra of $B$. ovalifoliolata bark extract and sample, change in wave number of the functional groups was observed due to the reduction and stabilization of metal group Zn (Sri Sindhura et al. 2013).

\section{XRD analysis}

XRD patterns of BZnNPs nanoparticles showed the peaks corresponding to Bragg's diffraction signals from the crystal planes (100), (002), (101), (102), (110), (103), (200), (112), (201), (004), and (201). The intensity data were collected over a $2 \theta$ range of $20^{\circ}-80^{\circ}$. A definite line broadening of the XRD peaks indicates that the prepared material consists of particles in nanoscale range (Fig. 5). The diffraction peaks located at $31.84^{\circ}, 34.52^{\circ}, 36.33^{\circ}$, $47.63^{\circ}, 56.71^{\circ}, 62.96^{\circ}, 68.13^{\circ}, 69.18^{\circ}, 70.16^{\circ}, 73.21^{\circ}$, and $78.56^{\circ}$ have been indexed as hexagonal wurtzite phase of $\mathrm{ZnO}$ (Khoshhesab et al. 2011) and further it also confirms that the synthesized nanopowder was free of impurities as it does not contain any characteristics XRD peaks other than $\mathrm{ZnO}$.

\section{Dynamic light scattering analysis}

Particle size and zeta potential values were measured using Nanopartica SZ-100 (HORIBA). The particle size distribution spectra for the zinc oxide nanoparticles were recorded as diameter $(\mathrm{nm})$ versus frequency $(\% / \mathrm{nm})$ 
Fig. 3 UV-visible spectroscopic micrograph showing $\mathrm{Zn}$ nanoparticles $(240 \mathrm{~nm})$ synthesized using $B$. ovalifoliolata stem bark extract
Fig. 4 FT-IR spectroscopic micrograph representing the functional groups responsible. For the reduction and stabilization of $\mathrm{Zn}$ nanoparticles synthesized using the aqueous extract of B. ovalifoliolata stem bark
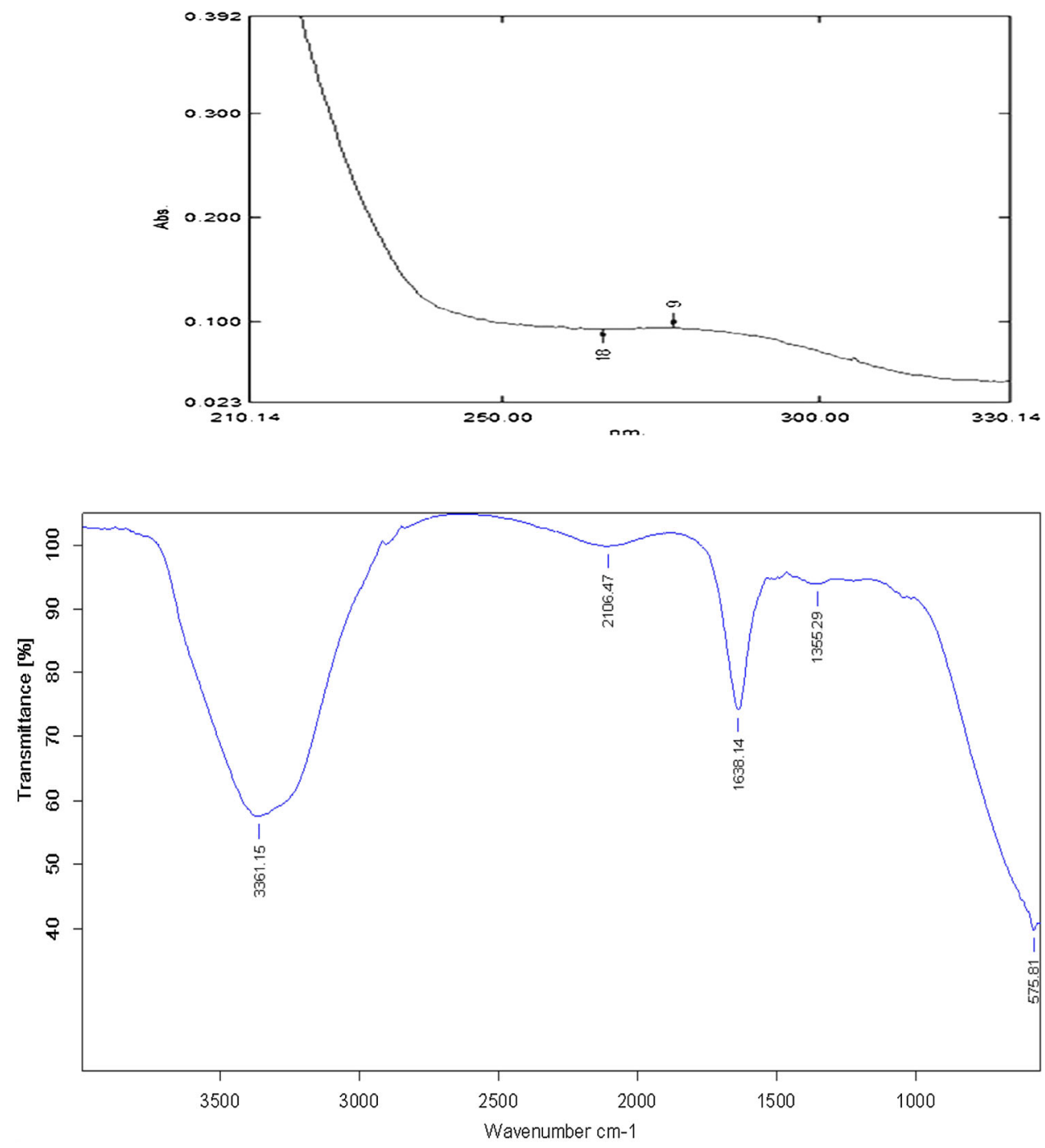

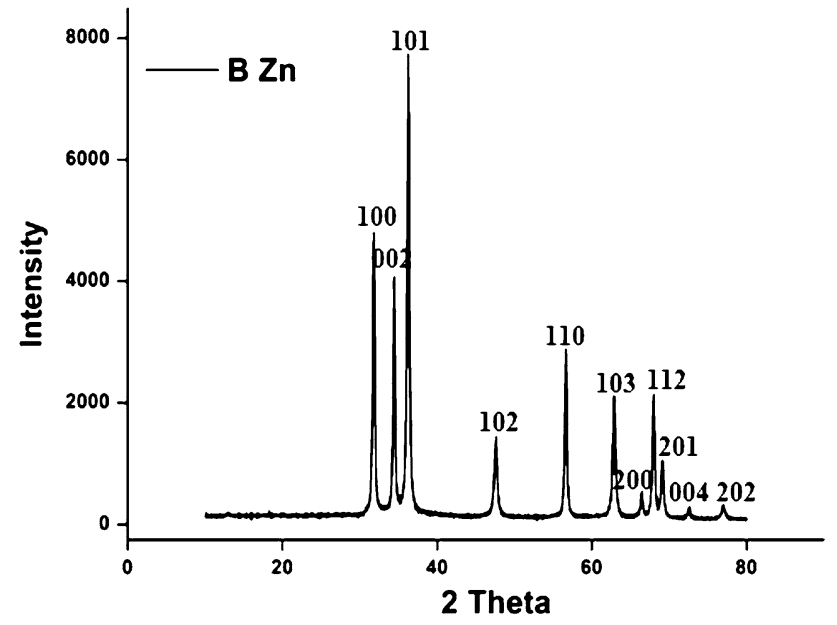

Fig. 5 XRD micrograph of Zinc nanoparticles synthesized using stem bark extract of Boswellia ovalifoliolata spectra with diameter $(\mathrm{nm})$ on $\mathrm{x}$-axis and frequency $(\% /$ $\mathrm{nm}$ ) on $\mathrm{y}$-axis. The zeta potential spectra for the zinc oxide nanoparticles were recorded zeta potential verses intensity spectra with zeta potential $(\mathrm{mV})$ on $\mathrm{x}$-axis and intensity (a.u) on y-axis. Particle size of $20.3 \mathrm{~nm}$ and zeta potential of $4.8 \mathrm{mV}$ were recorded (Fig. 6a, b) which signify the presence of repulsive electro-static forces among the synthesized zinc nanoparticles, which leads to the monodispersity of the particles. If the hydrosols have a large negative or positive zeta potential then they will tend to repel with each other and there will be no tendency of the particles to agglomerate. For the zinc nanoparticles synthesized from $B$. ovalifoliolata bark extract, least particle size and high zeta potential values were recorded. However, if the particles have low zeta potential values then there will be no force to prevent the particles coming together and flocculating (Roy et al. 2013). 

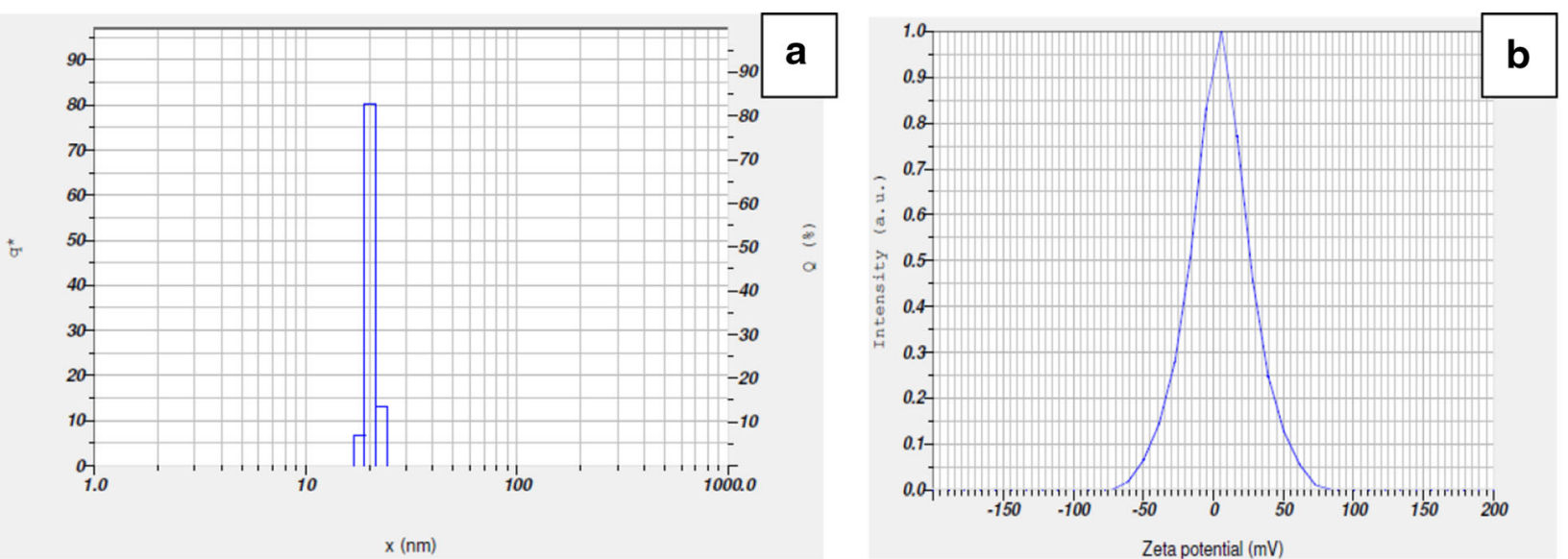

Calculation Results

\begin{tabular}{|c|c|c|c|c|}
\hline Peak No. & S.P.Area Ratio & Mean & S. D. & Mode \\
\hline 1 & 1.00 & 20.4 nाiा & $1.1 \mathrm{~nm}$ & $20.3 \mathrm{~nm}$ \\
\hline 2 & - & $=$ - 而而 & $=$ - & $-\pi \mathrm{nm}$ \\
\hline$\overline{3}$ & - & $-\mathrm{nm}$ & $=-\mathrm{nm}$ & $-\mathrm{nm}$ \\
\hline Total & 1.00 & $20.4 \mathrm{~nm}$ & $1.1 \mathrm{~nm}$ & $20.3 \mathrm{~nm}$ \\
\hline
\end{tabular}

Calculation Results

\begin{tabular}{|c|c|c|}
\hline Peak No. & Zeta Potential & Electrophoretic Mobility \\
\hline 1 & $4.8 \mathrm{mV}$ & $0,000038 \mathrm{~cm} 2 / \mathrm{ss}$ \\
\hline 2 & $-m \mathrm{mV}$ & $=\mathrm{cm} 2 / \mathrm{s}$ \\
\hline 3 & $==\mathrm{mV}$ & $=\mathrm{cm} 2 \mathrm{Vs}$ \\
\hline \multicolumn{2}{|c|}{ Zeta Potential (Mean) } & $: 4$ \\
\hline Electropl & oretic Mobill & y mean \\
\hline
\end{tabular}

Fig. 6 a, b The histogram (size distribution) of silver nanoparticles (dynamic light scattering) and zeta potential (4.8 mV) of $\mathrm{Zn}$ nanoparticles synthesized using Boswellia ovalifoliolata stem bark extract

\section{TEM analysis}

Zinc oxide nanoparticles used in this study are having the mean diameter of $20 \mathrm{~nm}$ as shown by TEM micrographs (Fig. 7). The formed BZnNPs appears slightly aggregated due to the absence of strong surface protecting ligands and found to be spherical in shape. The particles were crystalline in nature as revealed by the XRD analysis.

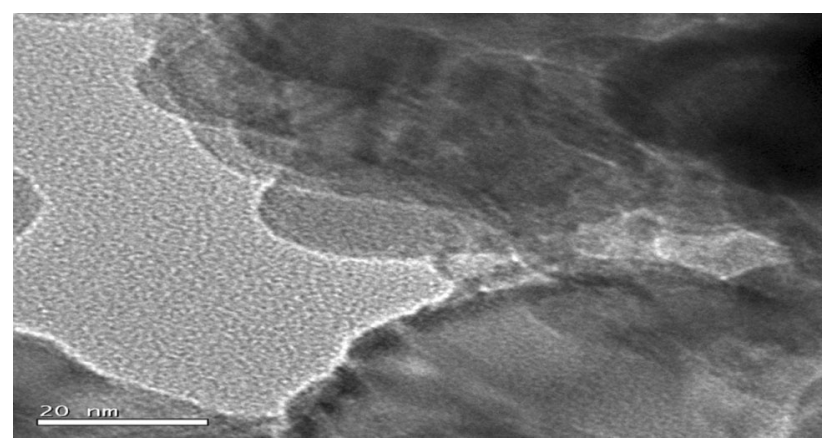

Fig. 7 TEM image of Boswellia ovalifoliolata stem bark-extractmediated synthesis of $\mathrm{Zn}$ nanoparticles showing spherical-shaped particles

\section{Antimicrobial efficacy of Boswellia ovalifoliolata stem bark-extract-mediated Zn nanoparticles}

BZnNPs have very strong inhibitory action against fungal sp, Gram-positive, and Gram-negative bacteria (Plates 1 and 2). Three concentrations of BZnNPs $(170,100$, and $50 \mathrm{ppm}$ ) were prepared and applied against an array of fungal species viz, Meyerozyma caribbica, Aspergillus parvisclerotigenus, Meyerozyma guilliermondii, Rhizopus oryzae, Uncultured fungus clone, Aspergillus oryzae, Trichoderma asperellum and bacterial species viz., Sphingobacterium thalpophilum, Uncultured organism clone, Ochrobactrum sp., Uncultured Achromobacter sp., Uncultured bacterium clone, Sphingobacterium sp., Acinetobacter sp., Uncultured soil bacterium, Ochrobactrum $\mathrm{sp}$, which were isolated from drinking water PVC pipes. The higher concentration $(170 \mathrm{ppm})$ of ZNPs showed significant antimicrobial effect (Tables 1, 2) compared with other concentrations (100 and $50 \mathrm{ppm})$. Similar results were obtained with the $170 \mathrm{ppm}$ concentration of the silver nanoparticles against an array of microbes (Grace and Pandian 2007).

The enhanced antimicrobial activity of nanoparticles can be attributed to their increased surface area available for interactions, which enhances bactericidal effect than the large sized particles; hence, they impart cytotoxicity to the 


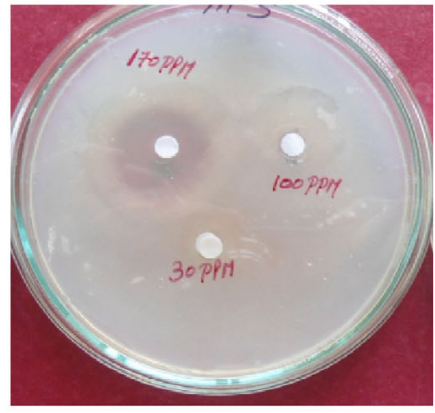

Sphingobacterium thalpophilum

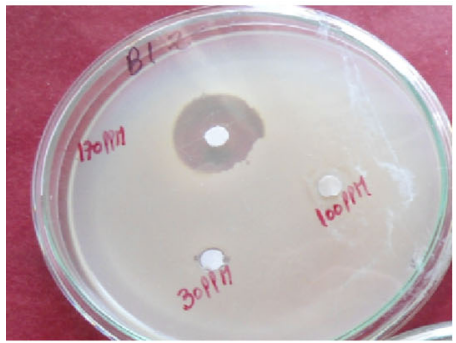

Uncultured Achromobacter sp

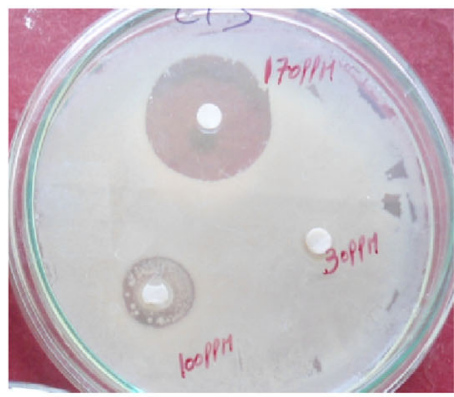

Acinetobacter $s p$

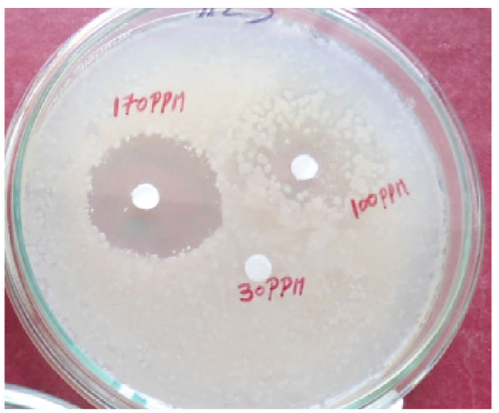

Uncultured organism clone

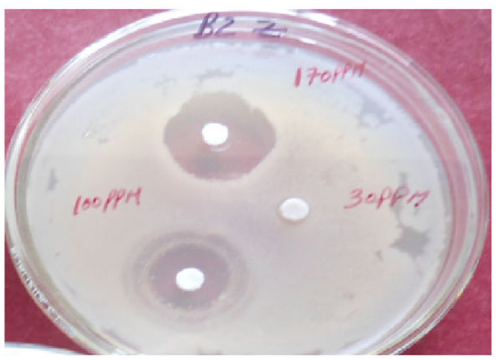

Uncultured bacterium clone

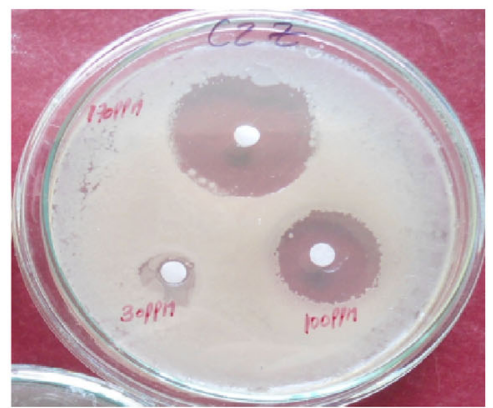

Uncultured soil bacterium

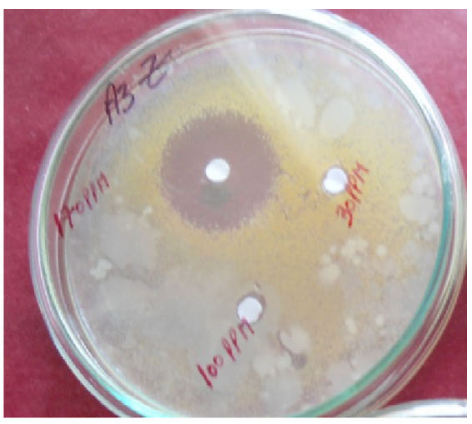

Ochrobactrum $s p$

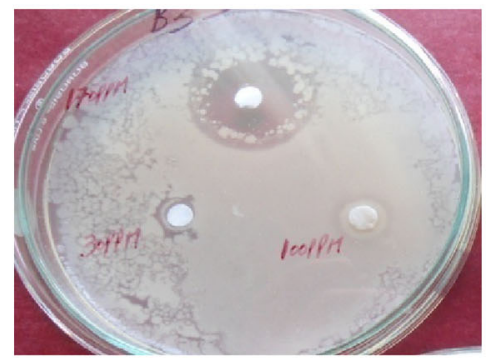

Sphingobacterium $s p$

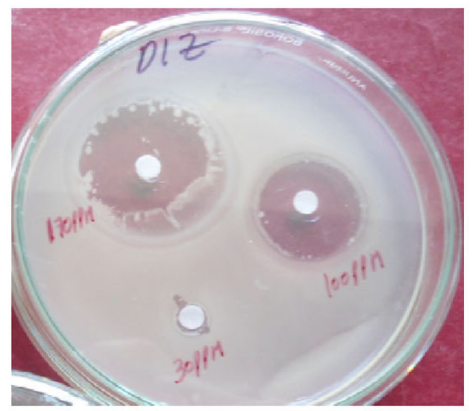

Ochrobactrum $s p$

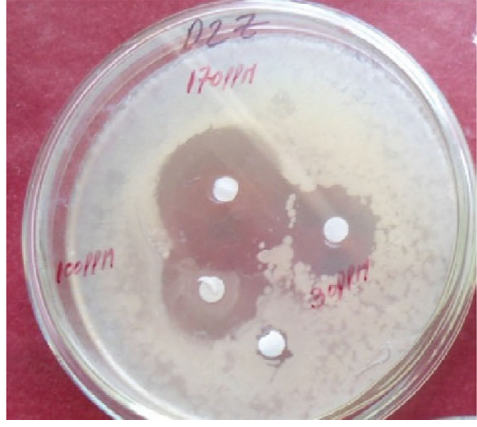

Uncultured bacterium

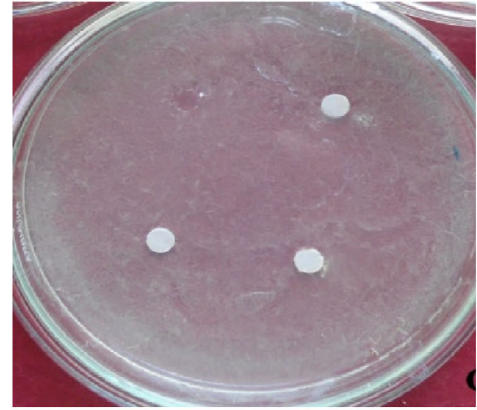

Control

Plate 1 Antibacterial activity of Boswellia ovalifoliolata stem bark-extract-mediated Zn nanoparticles against Gram-positive and Gram-negative bacteria

microorganisms (Adams et al. 2006). The mechanism by which the nanoparticles are able to penetrate the bacteria is not understood completely, but studies suggest that when bacteria were treated with zinc nanoparticles, changes took place in its membrane morphology that produced a significant increase in its permeability affecting proper transport through the plasma membrane (Auffan et al. 2009; Brayner et al. 2006), leaving the bacterial cells 


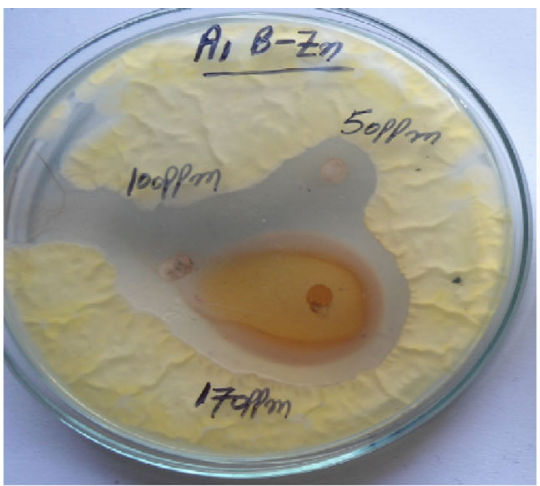

Meyerozyma caribbica

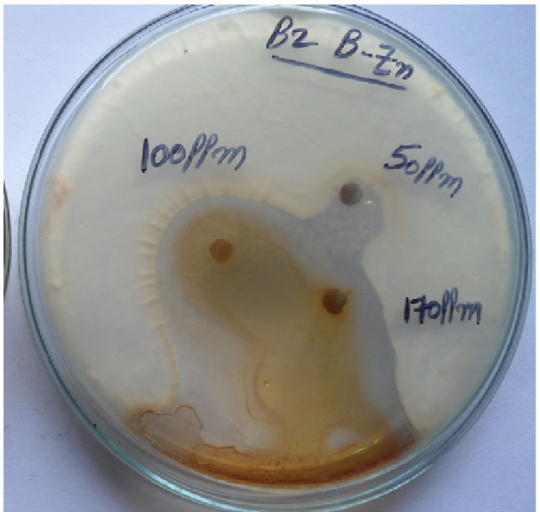

Rhizopus oryzae

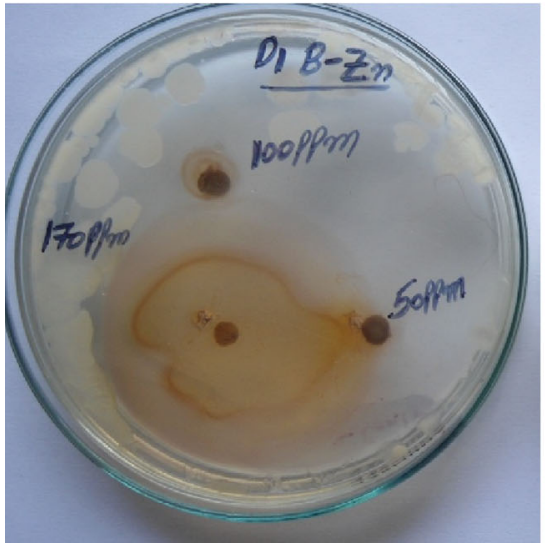

Trichoderma asperellum

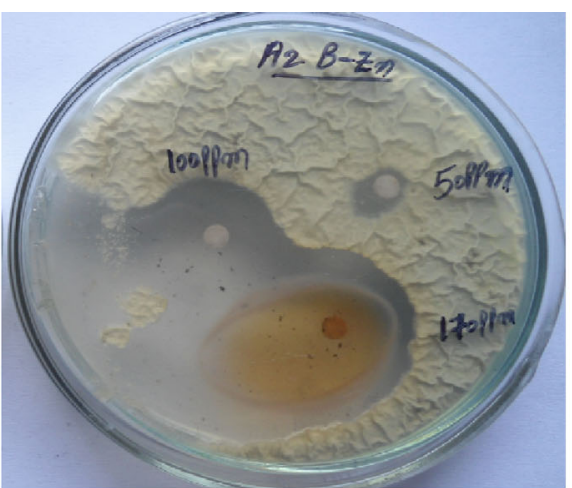

Aspergillus parvisclerotigenus

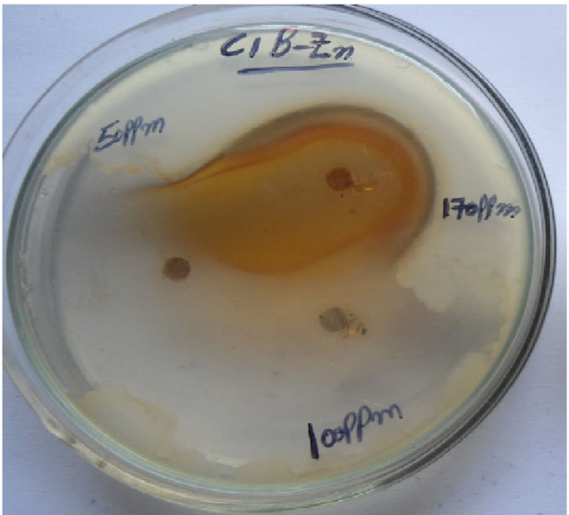

Uncultured fungus clone

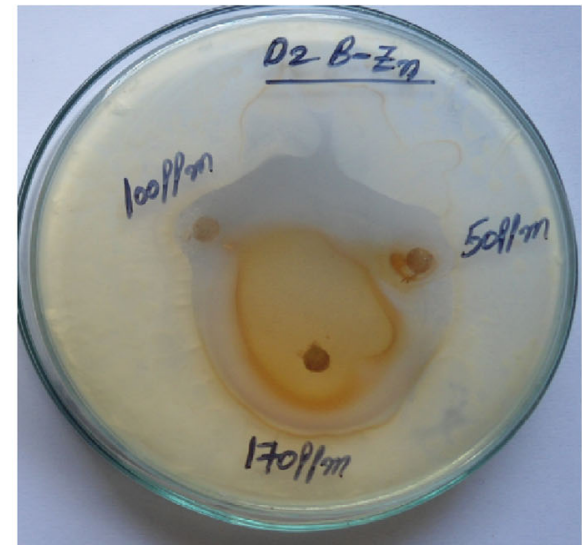

Meyerozyma caribbica

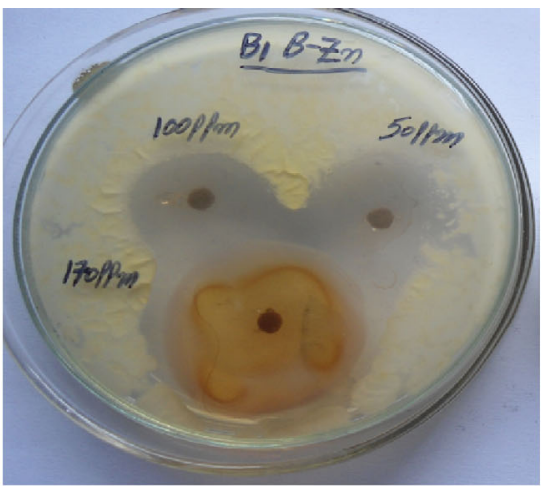

Meyerozyma guilliermondii

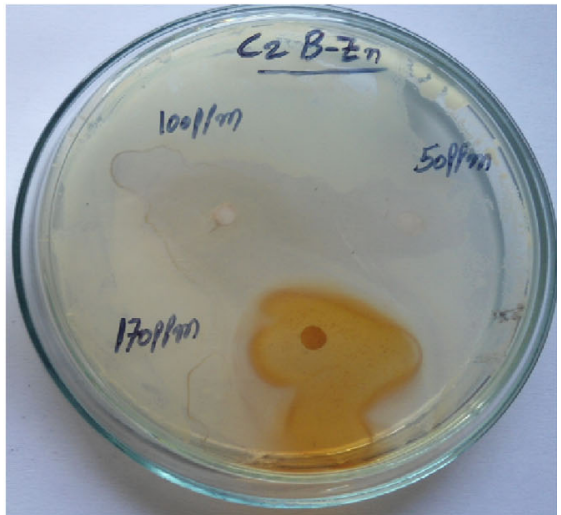

Aspergillus oryzae

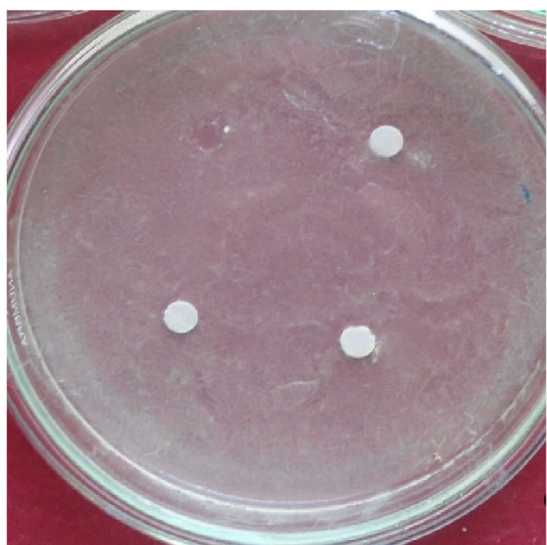

Control

Plate 2 Antifungal activity of different concentrations (50,100, and170 ppm) of Boswellia ovalifoliolata stem bark-extract-mediated ZnNPs

incapable of properly regulating transport through the plasma membrane, resulting into cell death (Dumas et al. 2009). It is observed that zinc nanoparticles have penetrated inside the bacteria and have caused damage by interacting with phosphorus- and sulfur-containing compounds such as DNA (He et al. 2008; Kim et al. 2003; Kirchner et al. 2005; Bayandori et al. 2008). Several investigations have suggested the possible mechanisms involving the interaction of nano-materials with the biological macromolecules. It is believed that microorganisms carry a negative charge while metal oxides carry a positive charge. This creates an "electromagnetic" attraction between the microbe and treated surface. Zinc nanoparticles synthesized from the $B$. ovalifoliolata stem bark extract proved to be more potent the antimicrobial activity is probably derived, through the electrostatic attraction between negative-charged cell membrane of microorganism and positive-charged nanoparticles (Prasad 
Table 1 In vitro antibacterial studies of bacteria present in drinking water PVC pipelines using Boswellia ovalifoliolata Zinc nanoparticles as inhibitors

\begin{tabular}{|c|c|c|c|c|}
\hline \multirow[t]{2}{*}{ S. no } & \multirow[t]{2}{*}{ Bacteria } & \multicolumn{3}{|c|}{ B.ovalifoliolata stem bark-extract-mediated synthesis of Zinc nanoparticles Zone of inhibition (mm) } \\
\hline & & $170 \pm 1.4 \mathrm{ppm}$ & $100 \pm 1.1 \mathrm{ppm}$ & $50 \pm 0.9 \mathrm{ppm}$ \\
\hline 1. & Sphingobacterium thalpophilum & $1.5^{\mathrm{bc}}$ & $1.2^{\mathrm{f}}$ & $0.9^{\mathrm{bcd}}$ \\
\hline 2. & Uncultured organism clone & $2.5^{\mathrm{a}}$ & $1.5^{\mathrm{c}}$ & $1.0^{\mathrm{ab}}$ \\
\hline 3. & Ochrobactrum sp. & $1.2^{\mathrm{d}}$ & $1.0 \mathrm{fg}$ & $0.8^{\mathrm{de}}$ \\
\hline 4. & Uncultured Achromobacter sp. & $1.2^{\mathrm{d}}$ & $1.0^{\mathrm{fg}}$ & $0.9^{\text {bcde }}$ \\
\hline 5. & Uncultured bacterium clone & $1.8^{\mathrm{b}}$ & $1.5^{\mathrm{cd}}$ & $0.7^{\mathrm{f}}$ \\
\hline 6. & Sphingobacterium sp. & $3.0^{\mathrm{a}}$ & $2.5^{\mathrm{a}}$ & $2.0^{\mathrm{a}}$ \\
\hline 7. & Acinetobacter sp. & $1.7^{\mathrm{bc}}$ & $1.5^{\text {cde }}$ & $1.0^{\mathrm{abc}}$ \\
\hline 8. & Uncultured soil bacterium & $2.9^{\mathrm{a}}$ & $2.4^{\mathrm{ab}}$ & $1.1^{\mathrm{a}}$ \\
\hline 9. & Ochrobactrum sp. & $4.0^{\mathrm{a}}$ & $2.5^{\mathrm{ab}}$ & $1.5^{\mathrm{a}}$ \\
\hline 10 & Uncultured bacterium & $1.7^{\mathrm{bc}}$ & $1.5^{\text {cde }}$ & $0.7^{\mathrm{f}}$ \\
\hline \multicolumn{2}{|c|}{$\mathrm{CD}(P=0.05)$} & 0.227 & 0.256 & 0.148 \\
\hline
\end{tabular}

Data followed by the same letter are not significantly different at $P \leq 0.05$, where as those followed by different letters are significantly different at $P \leq 0.05$

Table 2 In vitro antifungal studies of fungi present in drinking water PVC pipelines using Boswellia ovalifoliolata Zinc nanoparticles as inhibitors

\begin{tabular}{lllll}
\hline S. no & Fungi & \multicolumn{2}{l}{ B. ovalifoliolata stem bark-extract-mediated synthesis of Zinc nanoparticles Zone of inhibition (mm) } \\
\cline { 3 - 5 } & & $170 \pm 1.4 \mathrm{ppm}$ & $100 \pm \mathrm{ppm}$ & $50 \pm \mathrm{ppm}$ \\
\hline 1. & Meyerozyma caribbica & $3.0^{\mathrm{f}}$ & $2.2^{\mathrm{bcde}}$ & $1.7^{\mathrm{b}}$ \\
2. & Aspergillus parvisclerotigenus & $3.2^{\mathrm{ef}}$ & $2.5^{\mathrm{ab}}$ & $1.0^{\mathrm{de}}$ \\
3. & Meyerozyma guilliermondii & $4.5^{\mathrm{bc}}$ & $2.5^{\mathrm{abc}}$ & $2.2^{\mathrm{a}}$ \\
4. & Rhizopus oryzae & $4.6^{\mathrm{ab}}$ & $2.6^{\mathrm{a}}$ & $1.1^{\mathrm{d}}$ \\
5. & Uncultured fungus clone & $3.5^{\mathrm{e}}$ & $2.1^{\mathrm{e}}$ & $1.5^{\mathrm{bc}}$ \\
6. & Aspergillus oryzae & $4.5^{\mathrm{bcd}}$ & $2.5^{\mathrm{abcd}}$ & $1.7^{\mathrm{bc}}$ \\
7. & Trichoderma asperellum & $5.0^{\mathrm{a}}$ & $3.5^{\mathrm{a}}$ & $2.2^{\mathrm{a}}$ \\
8. & Meyerozyma caribbica & $4.2^{\mathrm{bcd}}$ & $2.2^{\mathrm{bcde}}$ & $1.1^{\mathrm{de}}$ \\
$\mathrm{CD}(P=0.05)$ 0.486 & & 0.310 & 0.210 \\
\hline
\end{tabular}

Data followed by the same letter are not significantly different at $P \leq 0.05$, where as those followed by different letters are significantly different at $P \leq 0.05$

et al. 2011). But to understand the mechanisms of action of these agents, more detailed chemical structure elucidation of the bioactive components followed by therapeutic investigations and toxicological assessment are required.

\section{Conclusion}

Synthesis of zinc oxide nanoparticles from B. ovalifoliolata stem bark extract was demonstrated. Zinc oxide nanoparticles were synthesized from $B$. ovalifoliolata stem bark extract showed good antimicrobial activity against bacteria and fungi. Maximum zone of inhibition was identified at $170 \mathrm{ppm}$ when compared to 100 and $50 \mathrm{ppm}$. Moreover, BZnNPs showed good antibacterial activity compared to antifungal activity. The findings in this study may lead to the development of BZnNPs-based new antimicrobial systems for medical applications.

Open Access This article is distributed under the terms of the Creative Commons Attribution 4.0 International License (http://creativecommons.org/licenses/by/4.0/), which permits unrestricted use, distribution, and reproduction in any medium, provided you give appropriate credit to the original author(s) and the source, provide a link to the Creative Commons license, and indicate if changes were made.

\section{References}

Adams LK, Lyon DY, Alvarez PJJ (2006) Comparative eco-toxicity of nanoscale $\mathrm{TiO}_{2}, \mathrm{SiO}_{2}$, and $\mathrm{ZnO}$ water suspensions. Water Res 40:3527-3532 
Auffan M, Rose J, Bottero JY, Lowry GV, Jolivet JP, Wiesner MR (2009) Towards a definition of inorganic nanoparticles from an environmental, health and safety perspective. Nat Nanotechnol 4:634-641

Bayandori A, Moghaddam M, Kazemzad MR, Nabid HH (2008) Synthesis of $\mathrm{ZnO}$ nanoparticles and electro deposition of polypyrrole/ZnO nano composite film. Int $\mathrm{J}$ Electrochem Sci 3:291

Bhattacharya S, Zaman MK (2005) Antibacterial activity of root of Indian zanthoxylum nitidum. Asian J Pharm Clin Res 25:199

Brayner R, Ferrari-Iliou R, Brivois N, Djediat S, Benedetti MF, Fievet F (2006) Toxicological impact studies based on Escherichia coli bacteria in ultrafine $\mathrm{ZnO}$ nanoparticles colloidal medium. Nano Lett 6:866-870

Cynthia H, Callaghan O (1983) Assessment of a new antibiotic. In: Hugo WB, Russel AD (eds) Pharmaceutical microbiology, 3rd edn. Blackwell Scientific Publications, Oxford, pp 122-134

Dumas EM, Ozenne V, Mielke RE, Nadeau JL (2009) Toxicity of CdTe quantum dots in bacterial strains. IEEE Trans Nanobiosci 8:58-64

Elechiguerra JL, Burt JL, Morones JR, Camacho-Bragado A, Gao X, Lara HH, Yacaman MJ (2005) Interaction of silver nanoparticles with HIV-1. J Nanobiotechnol 3:6. doi:10.1186/1477-3155-3-6

Girija S, Balachandran YL, Kandakumar J (2009) Plants as green nanofactories: application of plant biotechnology in nanoparticle synthesis. Plant Cell Biotechnol Mol Biol 10:79-86

Gunalan S, Rajeshwari S, Venkatesh R (2012) Green synthesized $\mathrm{ZnO}$ nanoparticles against bacterial and fungal pathogens. Prog Nat Sci 22:693-700

He Y, Wan TJM, Tokunaga T (2008) Kinetic stability of hematite nanoparticles: the effect of particle sizes. J Nanoparticle Res 10:321-332

Huang MH, Mao S, Feick H, Yan HQ, Wu Y, Kind H, Weber E, Russo R, Yang P (2001) ZnO microrods photodeposited with $\mathrm{Au}-\mathrm{Ag}$ nanoparticles: synthesis, characterization and application. In Sers. Science 292:1897

Kaushik N, Thakkar MS, Snehit S, Mhatre MS, Rasesh Y (2010) MS Biological synthesis of metallic nanoparticles. Nanomed Nanotechnol Biol Med 6:257-262

Khoshhesab ZM, Sarfaraz M, Asadabad MA (2011) Preparation of $\mathrm{ZnO}$ nanostructures by chemical precipitation meyhod. Synth React Inorg Met Org Nano Met Chem 7:814-819

Kim YS, Seo JH, Cha HJ (2003) Enhancement of heterologous protein expression in Escherichia coli by co-expression of nonspecific DNA-binding stress protein, Dps. Enzym Microbial Technol 4:460-465

Kim S, Kim J, Lee I (2011) Effects of and ZnO nanoparticles and $\mathrm{Zn}^{2+}$ on soil enzyme activity and bioaccumulation of $\mathrm{Zn}$ in Cucumis sativus. Chem Ecol 27:49-55

Kirchner C, Liedl T, Kudera S, Pellegrino T, Javier AM, Gaub HE, Stolzle S (2005) Cytotoxicity of colloidal CdSe and CdSe/ZnS nanoparticles. Nano Lett 5:331-338

Mohanpuria P, Rana NK, Yadav SK (2008) Biosynthesis of nanoparticles technological concepts and future applications. J Nanopart Res 10:507

Grace AN, Pandian K (2007) Antibacterial efficacy of aminoglycosidic antibiotics protected gold nanoparticles-a brief study. Colloids Surf A 297:6
Padil VVT, Cernik M (2013) Green synthesis of copper oxide nanoparticles using gum karaya as a biotemplate and their antibacterial application. Int J Nanomed 8:889-898

Prabha S, Supraja N, Garud M, Prasad TNVKV (2014) Synthesis, characterization and antimicrobial activity of Alstonia scholaris bark-extract-mediated silver nanoparticles. J Nanostruct Chem. doi:10.1007/s40097-014-0132-Z

Prasad TNVKV, Elumalai EK, Khateeja S (2011) Evaluation of the antimicrobial efficacy of phytogenic silver nanoparticles. Asian Pac J Trop Biomed 82-85

Prasad TNVKV, Sudhakar P, Sreenivasulu Y, Latha P, Munaswamy V, Raja Reddy K, Sreeprasad TS, Sajanlal PR, Pradeep T (2012) Effect of nanoscale zinc oxide particles on the germination, growth and yield of peanut. J Plant Nutr 35:905-927

Rai M, Yadav A, Gade A (2009) Silver nanoparticles as a new generation of antimicrobials. Biotechnol Adv 27:76-83

Reeves W, White A (1999) Clinical antimicrobial assay. Oxford University Press, New York, USA

Revina AA, Oksentyuk EV, Fenin AA (2007) Synthesis and properties of zinc nanoparticles: the role and prospects of radiation chemistry in the development of modern nanotechnology. Prot Met 43:613-618

Roy S, Triparna M, Shatarupa T, Das P (2013) Biosynthesis, characterization and antifungal activity of silver nanoparticles synthesized by the fungus Aspergillus foetidus MTCC8876. Dig J Nanomater Biostructures 8:197-205

Salam HA, Rajiv P, Kamaraj M, Jagadeeswaran P (2012) Green route for nanoparticle synthesis. Int Res J Biol Sci 1:85-90

Sap-Iam N, Homklinchan C, Larpudomlert R, Warisnoicharoen W, Sereemaspun A, Dubas ST (2010) UV irradiation-induced silver nanoparticles as mosquito larvicides. J Appl Sci 10:3132-3136

Sarkar R, Kumbhakar P, Mitra AK (2010) Green synthesis of silver nanoparticles and its optical properties. Dig J Nanomater Biostructures 5(2):491-496

Savithramma N (2011) Shorea tumbuggaia Roxb. An endemic endangered and medicinal tree taxon under threat. Non-wood News 22

Singh RP, Shukla KV, Yadav SR, Sharma KP, Singh KP, Pandey CA (2011) Biological approach of zinc oxide nanoparticles formation and its characterization. Adv Mater Lett 2:313-317

Sinha AK, Basu M, Pradhan M, Sarkar S, Pal T (2010) Fabrication of large-scale hierarchical $\mathrm{ZnO}$ hollow spheroids for hydrophobicity and photocatalysis. Chem A 16:7865-7874

Sreekanth TVM, Nagajyothi PC, Supraja N, Prasad TNVKV (2014) Evaluation of the antimicrobial activity and cytotoxicity of phytogenic gold nanoparticles. Appl Nanosci. doi:10.1007/ s13204-014-0354-x

Sri Sindhura K, Prasad TNVKV, Panner selvam P, Hussain OM (2013) Synthesis and characterization of phytogenic zinc nanoparticles and their antimicrobial activity. Appl Nanosci. doi:10.1007/s13204-013-0263-4

Sundrarajan M, Gowri S (2011) Green synthesis of titanium dioxide nanoparticles by Nyctanthes arbor-tristis leaves extract. Chalcogenide Lett 8:447-451

Yamac M, Bilgili F (2006) Antimicrobial activities of fruit bodies and/or mycelial cultures of some mushroom isolates. Pharm Biol 44:660-667 